\title{
Ampulla of Vater Cancer Pathologic Primary Tumor TNM Finding v8
}

National Cancer Institute

\section{Source}

National Cancer Institute. Ampulla of Vater Cancer Pathologic Primary Tumor TNM

Finding v8. NCI Thesaurus. Code C134845.

A pathologic finding about one or more characteristics of ampulla of Vater cancer,

following the rules of the TNM AJCC v8 classification system as they pertain to staging of the primary tumor. 